\title{
Pseudounicornuate uterus
}

\author{
INSERM
}

\section{Source}

INSERM. (1999). Orphanet: an online rare disease and orphan drug data base.

Pseudounicornuate uterus. ORPHA:180079

Pseudounicornuate uterus is a rare, non-syndromic uterovaginal malformation

characterized by a crescent-shaped, small-sized uterus containing a single horn and

fallopian tube associated with a rudimentary second horn (which can be solid or contain a

cavity with functioning endometrium and be communicating or non-communicating).

Urinary tract anomalies are frequently associated. 